\title{
Unlocking the Potential of Higher Education by Serving the Common Good
}

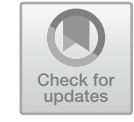

\author{
Patrick Blessinger, Enakshi Sengupta, and Mandla S. Makhanya
}

\section{Introduction}

The more pluralistic a society, the more diverse its educational system tends to be to address the diverse needs within society. No single institutional type and no single pedagogical approach can hope to address all the diverse educational and learning needs within society. In short, a one-size-fits-all approach to higher education is not well-suited to the modern age, which is increasingly characterized by diversity, complexity, uncertainty, risk, and hyper-connectivity. Furthermore, the democratic principles of inclusion, equity, justice, and rights require a more pluralistic structure to meet the diverse needs of society at all levels and in all segments. Therefore, a diverse higher education system is better able to promote the general well-being of society.

The argument and debate over higher education are often framed as a dichotomous question: Is the purpose of higher education to promote individual success or to promote the common good? But framing the question as an either/or question implies that the answer must be only one or the other. It further implies that higher education can only have one purpose or aim.

However, higher education has evolved over its nearly one-thousand-year history to perform three basic functions: teaching, research, and service. These three functions support its core purpose to produce learning (i.e., promote human development), and in so doing, it achieves its other aims such as forming more engaged citizens

P. Blessinger $(\varangle)$

St. John's University, New York, NY, USA

e-mail: patrickblessinger@gmail.com

P. Blessinger $\cdot$ E. Sengupta $\cdot$ M. S. Makhanya

International Higher Education Teaching and Learning Association, New York, NY, USA

e-mail: ekapur@gmail.com

M. S. Makhanya

University of South Africa, Pretoria, South Africa

e-mail:makhams@unisa.ac.za

(c) The Author(s) 2021 
(political/civic purpose), developing more productive workers (economic purpose), and creating more knowledgeable individuals (social/personal purpose) (Blessinger and Anchan 2015; Dorn 2017).

Furthermore, higher education has adapted to the changing political, economic, social, technological, and environmental landscapes over the past millennium. In an age where these landscapes are increasingly interconnected and interdependent, the sustainability of the planet is increasingly linked to and dependent upon how well humans promote the common good. By promoting common interests, humans are also promoting their individual interests and needs.

Evolution has allowed humans to become the dominant species on the planet. This has led to both positive and negative consequences. Not only does this give humans certain benefits and advantages over other species, but it also places on humans an ethical responsibility to be good stewards of the planet. Thus, the new realities of global warming, widespread destruction of ecosystems, pervasive loss of biodiversity, mass deforestation, rising sea levels, shrinking glaciers, increasingly erratic and unpredictable climate change, and increased social instability are likely linked to human-induced activities (Ford 2002, 2016).

Hence, while political, economic, social, and technological disruptions have generally yielded positive results in recent human history (for example, democratic revolution, industrial revolution, cultural revolution, and digital revolution, respectively), the concomitant environmental disruptions that have occurred over the past few hundred years have been largely negative and potentially irreversible. Thus, the next great challenge for higher education institutions is to prepare students and society to address these highly complex, intractable, and urgent questions (Blessinger 2018a,b).

\section{Development of Modern Higher Education}

\section{First wave: nineteenth century to 1945}

During the first wave of modern higher education, institutions began to adopt the Humboldtian model of higher education by integrating research and teaching. During this wave, higher education focused primarily on basic research to produce new knowledge to build out the academic disciplines with specialized knowledge bases. Since, during this time, human activity had relatively less impact on the global environment, applied research was largely a secondary focus. This wave also saw the initial growth of public universities (for example, community colleges and land grant universities in the USA) to bring higher learning to more people. Despite these efforts to bring higher learning to the masses, higher education was still, by and large, an elite higher education system. Martin Trow (1973) defined an elite higher 
education system as one that had up to a $15 \%$ participation rate of the relevant age group.

Second Wave: 1946-1980

After World War II, some countries experienced a huge increase in enrolment as nations shifted their focus from war-time activities to economy-building activities since these new economies required a more professionalized workforce (for example, scientists, engineers, architects, physicians, lawyers, managers, teachers). As such, the primary focus of colleges and universities shifted towards applied research by fostering such issues as democracy around the world, medical and technological inventions, social justice and human rights, and poverty and illiteracy reduction. It was also during this wave that the right to access education at all levels became established in various international laws and human rights documents such as the United Nations International Covenant on Economic, Social, and Cultural Rights (United Nations 1976). As a result, it was during this wave that higher education morphed from an elite system to a mass system of higher education (that is, a $16 \%$ to $50 \%$ participation rate).

\section{Third Wave: 1981-2015}

During the third wave, the world experienced major political, economic, social, and technological changes around the world. During this wave, new global technologies such as the internet spread rapidly and the number of countries that adopted democratic and capitalistic systems (in one form or another) increased significantly (Roser 2019). As a result, demand for higher learning surged as new business models, and delivery modes (e.g., online learning) became more prevalent. During this wave, participation rates in developed and developing countries continued to increase closer to universal rates (that is, over 50\% participation rate). Trow (1973) considered a participation rate of over $50 \%$ to be a system with open access.

\section{Fourth Wave: 2015 to present}

During the fourth wave, the United Nations created the Sustainable Development Goals, which outlined 17 goals that humanity needs to reach to create a more sustainable planet. These goals have become imperative because scientific research on climate change provides unequivocal evidence that human activity over the past few hundred years has severely degraded the planet. Thus, educating current and future generations on how to create a more sustainable planet for the common good is now necessary. As such, a new type of higher education system is needed and is slowly emerging, one that better serves the contemporary and future needs of humanity and the planet, one for the common good (Locatelli 2018, 2019). 


\section{Towards Education for the Common Good}

From an economic science perspective, a private good is a good that is both rivalrous and excludable, a public good is a good that is both non-rivalrous and non-excludable, and a common good is a good that is both rivalrous and non-excludable. Thus, common goods are those goods that are common resources (that is, freely available) but their supply is limited, and it is difficult to prevent people from consuming or hoarding as much as they want.

Examples of common goods include air, atmosphere, natural forests/minerals, wildlife, ecosystems, water, and rivers/lakes/oceans. In the absence of rules and collective action, individual self-interests often lead to abuse, exploitation, and depletion of common resources which, in turn, typically results in air, water, and land pollution, deforestation, severe depletion of natural resources, species/ecosystem extinction, climate change, and uncontrolled population growth (that is., the tragedy of the commons).

There are many different types and levels of education and learning (e.g., public, private, open, formal, non-formal). Thus, education, as well as learning and knowledge production and consumption, does not fit neatly and exclusively into a single box (category) based upon just a few narrow criteria (for example, rivalry and excludability). Furthermore, there are many ways, using different criteria, to classify goods and services.

Thus, to accommodate this situation and to take into account a broader set of criteria (for example, political, social, and environmental criteria) and to take a more holistic view of the education system, education is often classified as a merit good because of the huge positive externalities that it creates (for example, justice, economic growth, innovation, human capital, cultural capital, social capital). Regardless of the criteria used to define education, in a diverse society there exists many forms of education and learning to meet the diverse needs of the population.

Although the technical economic classification and definition of goods help us understand the concept, they are, nonetheless, insufficient. To better understand what is best for the common good (that is, the general well-being), a broader humanistic view of education is needed. From a broader humanistic view, the common good (that is, an ideal social outcome), as opposed to $a$ common good (that is, a specific type of good), can be considered as those shared benefits that are achieved by all members of society through shared values and collective action.

Thus, to achieve the most equitable and inclusive allocation of shared benefits for society, the democratic principles of rights and justice are instituted to promote and protect the common good. In addition, some self-interested behaviours such as rent-seeking behaviour (more aptly referred to as privilege-seeking behaviour) and free-riding behaviour can severely diminish the benefits of the common good. Therefore, reasonable rules and regulations are needed in order to promote and protect the common good. 
Furthermore, the narrow economic definition of goods has limitations from a humanistic perspective. Thus, an increasing number of scholars have advocated for a rights-based approach to higher education, such as Blessinger and Anchan (2015) and McGowan (2013). This rights-based approach lends itself to viewing education for the common good, which in turn, lends itself to promoting the idea of higher education for sustainable development. In 2015, in one of the greatest acts of global collective action, the world community developed the Sustainable Development Goals (United Nations 2015). It is now time for higher education institutions around the world to implement these goals into their missions, policies, and practices, including their teaching, research, and service functions.

Sustainable development is one of the most pressing issues of the current generation. Education at all levels should be recognized as a right whose remit serves the global common good (UNESCO 2015). As noted by Ford (2016, para. 14), “The only justification for an institution of higher education is that it serves the greatest needs of a particular civilization." Also, as Daviet (2016, p. 8) notes, "Finally, the concept of common good, encompassing ethical and political concerns, provides a principle to rethink the purpose of education." Finally, as noted by UNESCO (2015, p. 80), "Education and knowledge should be considered global common goods. The creation of knowledge, its control, acquisition, validation, and use, are common to all people as a collective social endeavour."

As noted by Blessinger (2018a, b), humanistic higher education is oriented around the principles of our shared humanity, such as equity, inclusion, justice, and rights. To that end, sustainable development becomes important because it serves the common good. Reorienting and reorganizing institutions of higher education to adopt the sustainable development goals should be one of the top priorities of our century. What is urgently needed, therefore, is a renewed vision of higher education and its role in the world.

\section{References}

Blessinger, P. \& Anchan, J. (2015). Democratizing higher education. Routledge Publishing.

Blessinger, P. (2018a). Higher education's key role in sustainable development. University World News. Retrieved from: https://www.universityworldnews.com/post.php? story $=20180905082834986(26.07 .2020)$

Blessinger, P. (2018b). A higher ideal for higher education, HERDSA CONNECT, Volume 40, Number 3, Spring 2018.

Daviet, B. (2016). Revisiting the principle of education as a public good. UNESCO. Retrieved from: https://unesdoc.unesco.org/ark:/48223/pf0000245306 (26.07.2020)

Dorn, C. (2017). For the common good: A new history of higher education in America. Cornell University Press.

Ford, M.P. (2002). Beyond the modern university: Toward a constructive postmodern university. Praeger Publishing. 
Ford, M.P. (2016). Education for the common good. AAUP. Retrieved from: https://www.aaup.org/ article/education-common-good\#.Xrgw_i-z3jA (26.07. 2020)

Locatelli, R. (2018). Education as a public and common good: reframing the governance of education in a changing context. UNESCO. Retrieved from: https://unesdoc.unesco.org/ark:/48223/ pf0000261614 (26.07.2020)

Locatelli, R. (2019). Reframing Education as a Public and Common Good: Enhancing Democratic Governance. Palgrave Macmillan.

McGowan, T. (2013). Education as a human right: Principles for a universal entitlement to learning. Bloomsbury Academic.

Roser, M. (2019). Number of democracies. Our World in Data. Retrieved from: https:// ourworldindata.org/democracy (26.07.2020)

Trow, M. (1973). Problems in the transition from elite to mass higher education. Carnegie Commission on Higher Education.

UNESCO (2015). Rethinking education: Towards a global common good. UNESCO Publishing. Retrieved from: https://unesdoc.unesco.org/ark:/48223/pf0000232555 (26.07.2020)

United Nations (1976). International Covenant on Economic, Social and Cultural Rights. Retrieved from: https://www.ohchr.org/Documents/ProfessionalInterest/cescr.pdf (26.07.2020)

United Nations (2015). Sustainable Development Goals. United Nations. Retrieved from: https:// sustainabledevelopment.un.org (26.07.2020)

Patrick Blessinger is an adjunct associate professor of education at St. John's University, an educator with the New York State Education Department, and chief research scientist of the International Higher Education Teaching and Learning Association (in consultative status with the United Nations). He is the editor and author of many books and articles, and he is an educational policy analyst and contributing writer with UNESCO's Inclusive Policy Lab, University World News, The Hechinger Report, The Guardian, and Higher Education Tomorrow, among others.

Enakshi Sengupta is director of the Center for Advanced Research in Education at HETL (International Higher Education Teaching \& Learning Association. She has been appointed as the Principal Strategic Advisor to HETL and will be responsible for reputation building and strategic alliances for HETL. She is also the Associate Series Editor of the book series, Innovations in Higher Education Teaching and Learning, Emerald Group Publishing. She is the Managing Editor of the Journal of Applied Research in Higher Education, Emerald Publishing, and serves as the Vice Chair of the Editorial Advisory Board of the Innovations in Higher Education Teaching and Learning, Emerald Publishing.

Mandla S. Makhanya is Principal and Vice-Chancellor of the University of South Africa and President of the Higher Education Teaching and Learning Association (HETL) - International Body. He is past President of the International Council for Distance Education (ICDE) and is also Treasurer of the African Council for Distance Education (ACDE). He is a Deputy Chairperson of the South African National Commission for UNESCO and Chairperson of the Culture Sector of the South African National Commission for UNESCO. 
Open Access This chapter is licensed under the terms of the Creative Commons Attribution 4.0 International License (http://creativecommons.org/licenses/by/4.0/), which permits use, sharing, adaptation, distribution and reproduction in any medium or format, as long as you give appropriate credit to the original author(s) and the source, provide a link to the Creative Commons license and indicate if changes were made.

The images or other third party material in this chapter are included in the chapter's Creative Commons license, unless indicated otherwise in a credit line to the material. If material is not included in the chapter's Creative Commons license and your intended use is not permitted by statutory regulation or exceeds the permitted use, you will need to obtain permission directly from the copyright holder. 